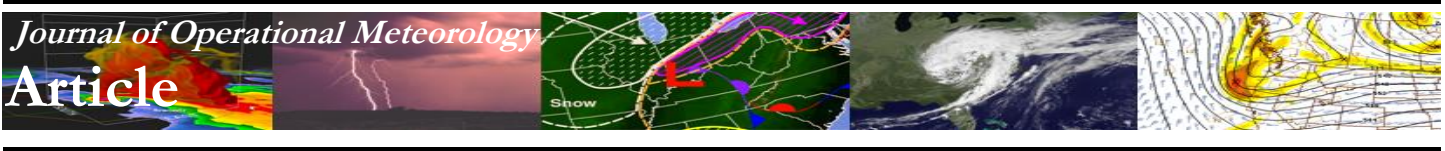

\title{
Independence Day Holiday Weekend 2010 Flood on the Southern Plains of West Texas
}

\author{
JEFFREY D. VITALE and JOHN LIPE \\ National Weather Service Lubbock, Texas \\ T. TODD LINDLEY \\ National Weather Service Amarillo, Texas
}

(Manuscript received 21 September 2014; review completed 17 March 2015)

\begin{abstract}
An exceptionally rare flood and flash flood took place on the southern plains of West Texas during the Independence Day holiday weekend of 2010. Several daily and monthly record rainfall totals were broken across a wide region during this multi-day event. Lubbock Preston Smith International Airport recorded a storm total rainfall of $155 \mathrm{~mm}(6.12 \mathrm{in})$ over four days and set daily records on 2-3 July when $56 \mathrm{~mm}(2.19 \mathrm{in})$ and $83 \mathrm{~mm}(3.27 \mathrm{in})$ were observed, respectively. The most notable impact was the failure of an earthen dam that emptied a $2.4 \times 10^{5} \mathrm{~m}^{2}$ (or 60 ac) lake along the Upper Brazos River. The resulting flood ruptured pipelines that led to an oil spill. Much of this excessive rainfall was due to the influence of moisture from the remnants of Hurricane Alex. This abundant tropical moisture set the stage to create heavy rainfall from 1 July through 4 July that reached a peak during the overnight of 3-4 July owing to a mesoscale convective vortex. Warm-rain precipitation production processes were greatly enhanced during this event and contributed to excessive heavy rainfall.
\end{abstract}

\section{Introduction}

Fatality and damage statistics from flash flooding can vary greatly across different regions of the United States based on several non-meteorological factors such as terrain and land use. In the West Texas region, flooding and flash flooding is an unusual event. This is due to mainly flat terrain across the region and the abundance of playa (Briere 2000) - or dry lakesacross the southern High Plains. Long periods of drought and wildfires are more common and have a larger impact in West Texas than flooding, but are not necessarily mutually exclusive (Lindley et al. 2011).

A historic flooding event occurred during the Independence Day holiday weekend of 2010 in West Texas that was a result of the remnants of Hurricane Alex. Tropical systems have been known to affect West Texas, although most previous documentation has referenced tropical systems with origins only in the eastern North Pacific Ocean (Bomar 1995). Very few tropical systems that originate in the Atlantic Ocean have a large impact in West Texas [National Hurricane Center (NHC) 2012]. Two previous tropical systems with origins in the Atlantic Ocean significantly affected West Texas-Celia in 1970 (Simpson and Pelissier 1971) and Claudette in 2003 (Lindley et. al. 2005). Two additional events, though originating in the eastern North Pacific Ocean, were similar to this one in historical significance: 10-12 September 2008 (Tropical Storm Lowell; Bosart et. al. 2012) and 1820 October 1983 (Hurricane Tico; Tumbiolo 1989). This paper will examine meteorological and hydrological issues and impacts from the remnants of Hurricane Alex across the southern plains of West Texas.

\section{Event overview and radar analysis}

Alex originated from an area of unsettled weather within the Intertropical Convergence Zone on 17 June. The storm first made landfall on 27 June near Belize City. Alex became a hurricane on 29 June while in the Bay of Campeche. Alex strengthened to a category 2 hurricane before landfall around 0000 UTC on 1 July, approximately $161 \mathrm{~km}(100 \mathrm{mi})$ south of Brownsville, Texas. This tropical system brought torrential rainfall from southern Mexico through the southern plains of 
the United States. Although its low-level circulation dissipated once Alex came onshore, the midlevel remnants continued to track westward and eventually northwest into the higher terrain of Mexico (Fig. 1). Orographic lift developed after the remnant midlevel circulation moved onshore and interacted with the Sierra Madre Oriental Mountains. This resulted in devastating rainfall in eastern Mexico for several days after the surface circulation had dissipated (Pasch 2010). Additionally, mid- and upper-level moisture associated with Alex continued to be directed northward into central and western Texas owing to an upper-level ridge located over southeastern Texas at $500 \mathrm{hPa}$.

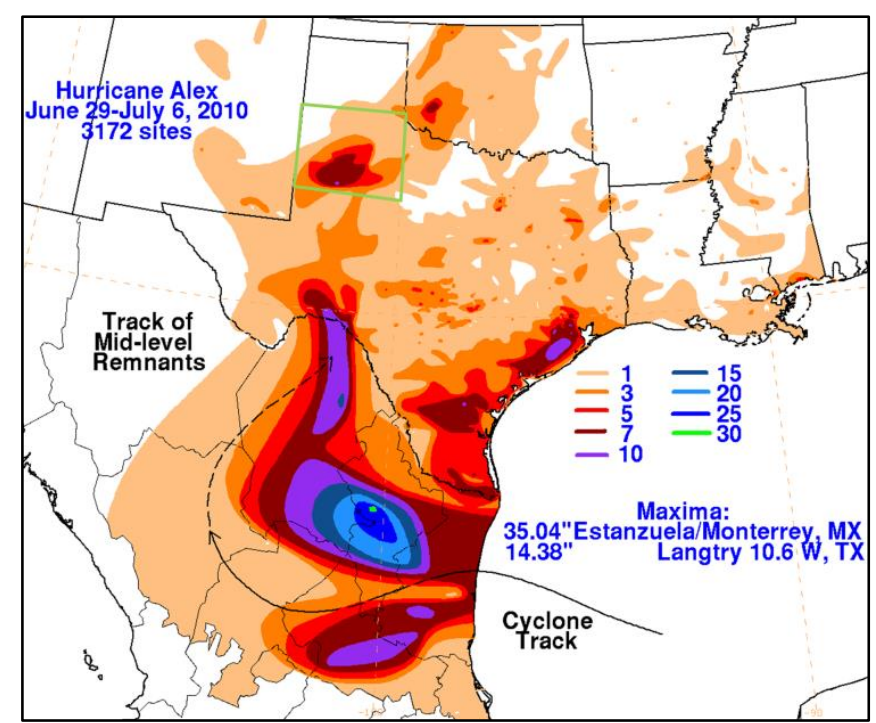

Figure 1. Graphic provided by the Weather Prediction Center that depicts the track of Alex and an estimate of rainfall (in; multiply by 25.4 for $\mathrm{mm}$ ). The Lubbock, TX, county warning area (CWA) is outlined in green for reference. Click image for an external version; this applies to all figures hereafter.

Mid- and upper-level tropical moisture from Alex played a major role in creating historic rainfall in the vicinity of Lubbock, Texas, over a 4-day period from 1 July through 4 July 2010. Several rainfall records were broken at Lubbock Preston Smith International Airport during this event. Additionally, several National Weather Service (NWS) cooperative weather observer sites documented record or near record 4-day rainfall totals. Although significant rainfall was observed over a 4-day period, the heaviest rain fell on the evening of 3 July into the early morning of 4 July. At times, rain rates were observed to be near $102 \mathrm{~mm} \mathrm{hr}^{-1}\left(4 \mathrm{in} \mathrm{hr}^{-1}\right)$ via the Texas Tech University West Texas mesonet observation network (Fig. 2). Heavy rain resulted in

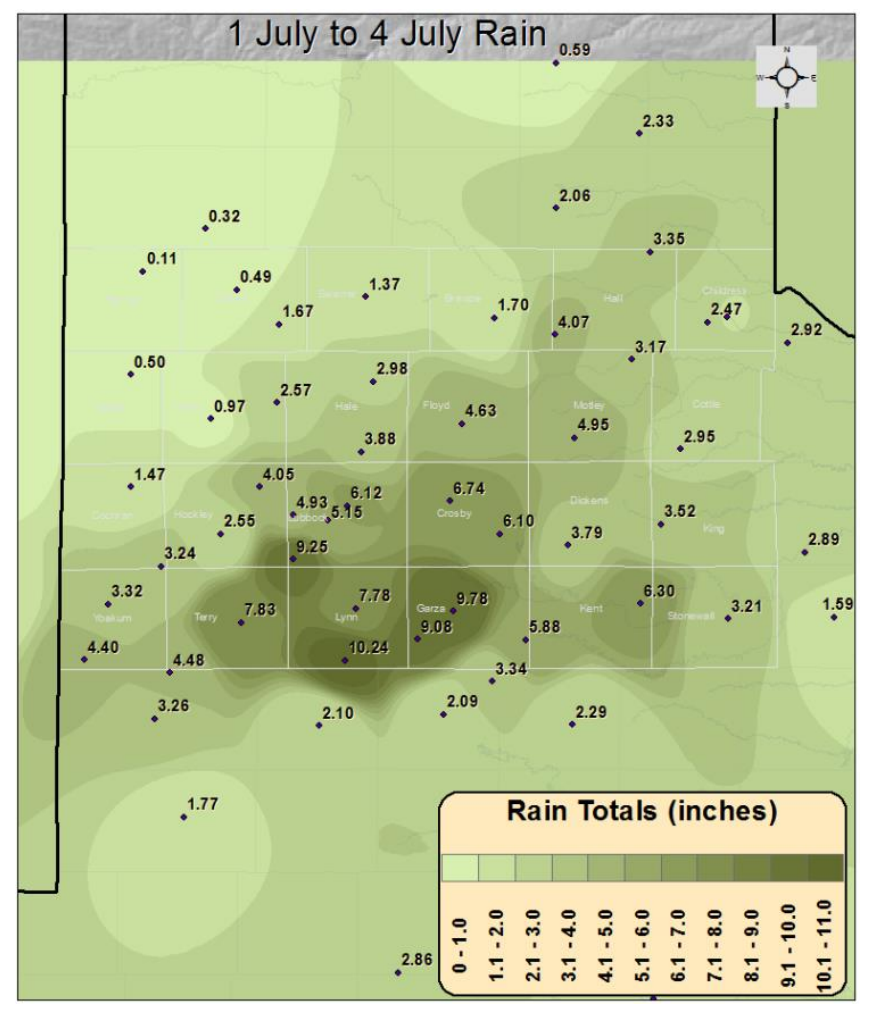

Figure 2. Total rainfall (in; multiply by 25.4 for $\mathrm{mm}$ ) observed by the Texas Tech University West Texas mesonet sites and automated surface observation locations. Lubbock CWA counties are labeled and outlined in white.

numerous high water rescues, road closures, river flooding, crop losses, prolific urban flooding, and an earthen dam failure at Stuart Lake in Lynn County, Texas. Further downstream near Lake Alan Henry, along the Double Mountain Fork of the Upper Brazos River, support beams for two oil lines were washed away (Fig. 3). As a result, 165 barrels of crude oil spilled into the river. Despite the historic flooding, no fatalities or significant injuries occurred. Total damages were estimated near $\$ 16.5$ million and several counties around Lubbock were declared disaster areas by the state of Texas (NCDC 2010).

Scattered showers and thunderstorms initially developed on the afternoon of 1 July (Fig. 4a) and continued on 2 July (Fig. 4b). Convective activity transitioned to excessively heavy tropical rainfall late on 3 July through early 4 July (Fig. 4c). Reflectivity values rarely exceeded 50-55 dBZ during the zenith of the event on the evening of 3 July through the early morning of 4 July. A radar cross section at 1137 UTC 4 July 2010 (Fig. 5) indicated that the largest reflectivities were below the $-10^{\circ} \mathrm{C}$ isotherm, with decreasing reflectivities above this height. In fact, the largest reflectivities were located below the $0^{\circ} \mathrm{C}$ 


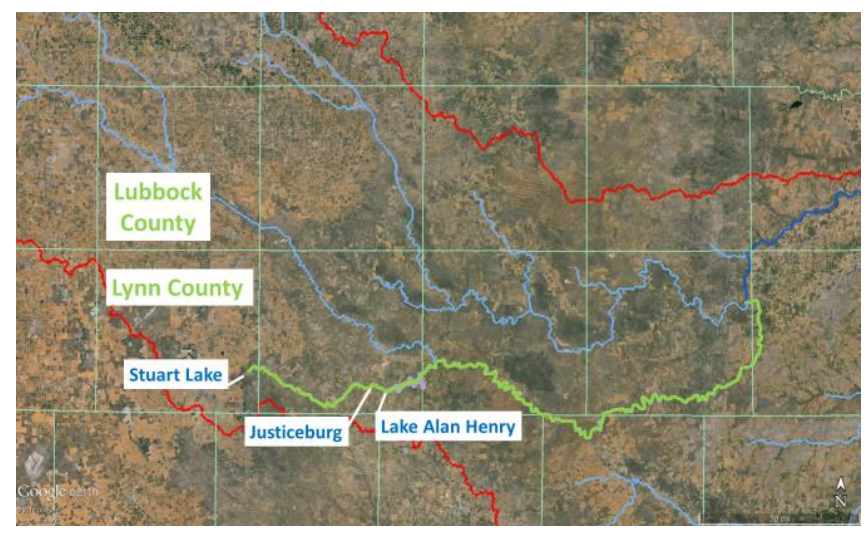

Figure 3. Google Earth image depicting the Upper Brazos River Basin. The green line represents the Double Mountain Fork of the Brazos River. The red line indicates the border of the river basin. Lubbock and Lynn Counties are labeled for reference.

isotherm. The largest radar reflectivities within the warm portion of the cloud have been shown to be an important consideration in excessive rainfall events (Xu et al. 2008; Vitale and Ryan 2013).

Maximum rainfall estimates (Fig. 6) from the Lubbock (KLBB) Weather Surveillance Radar-1998 Doppler (WSR-88D) were near $611 \mathrm{~mm}$ (24.07 in). For the duration of the event, the KLBB rainfall estimation employed the tropical $Z-R$ relationship (Rosenfield et al. 1993):

$Z=250 R^{1.2}$

where precipitation rate $(R)$ is derived using reflectivity $(Z)$. The largest measured rainfall total was 361 $\mathrm{mm}$ (14.2 in) near Draw, Texas, which is noted by the star on Fig. 6. Radar rainfall estimates depict $384 \mathrm{~mm}$ (15.12 in) at this location. The radar did reasonably well with rainfall estimates when comparing the storm total precipitation product with observed amounts (Fig. 7). Therefore, it would not be unreasonable to suggest that the maximum total of $611 \mathrm{~mm}$ (24.07 in) estimated by radar may be a slight overestimation. The warm-rain precipitation production process dominated throughout the event, which led to accurate radar rainfall estimates. However, during the afternoon each day of the event, a small amount of lightning was observed, which suggests that a small quantity of ice was introduced into the precipitation production process (Carey and Rutledge 2000). This has the effect of lessening the performance of the tropical $Z-R$ relationship. Furthermore, an additional consideration was the overshooting of the radar beam. When the largest reflectivities are in the lowest portion of the cloud, the radar beam can overshoot these reflectivities, resulting
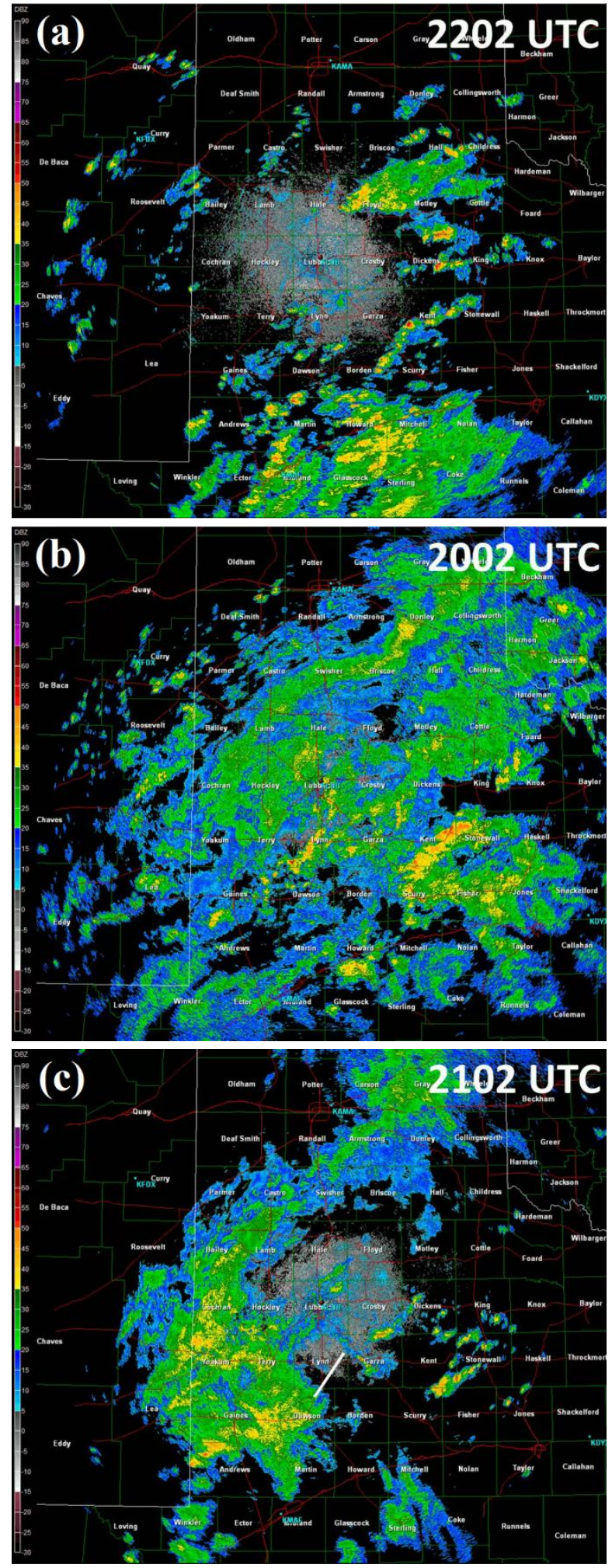

Figure 4. Animated radar images from KLBB for (a) 2202 UTC 1 July-0158 UTC 2 July, (b) 2002 UTC 2 July-0201 UTC 3 July, and (c) 2102 UTC 3 July-1301 UTC 4 July 2010. The thick white line in (c) indicates the location of the cross section in Fig. 5. Click each image for an external animation; if needed, help can be found at www.webmproject.org/users/\#supported_web_browsers. 


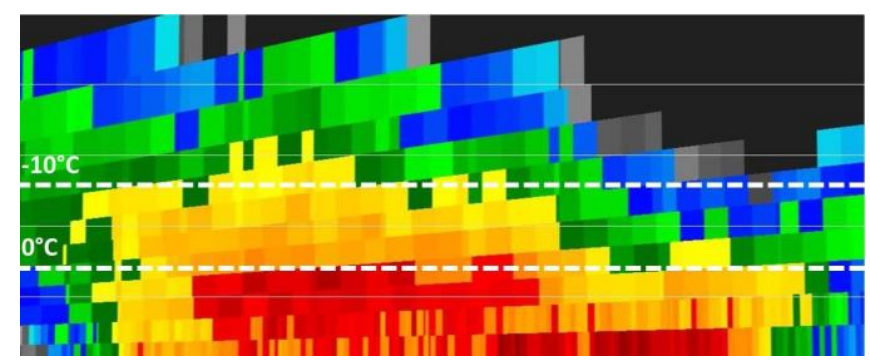

Figure 5. Radar cross section from KLBB at 1137 UTC 4 July 2010. Color scale is the same as in Fig. 4.

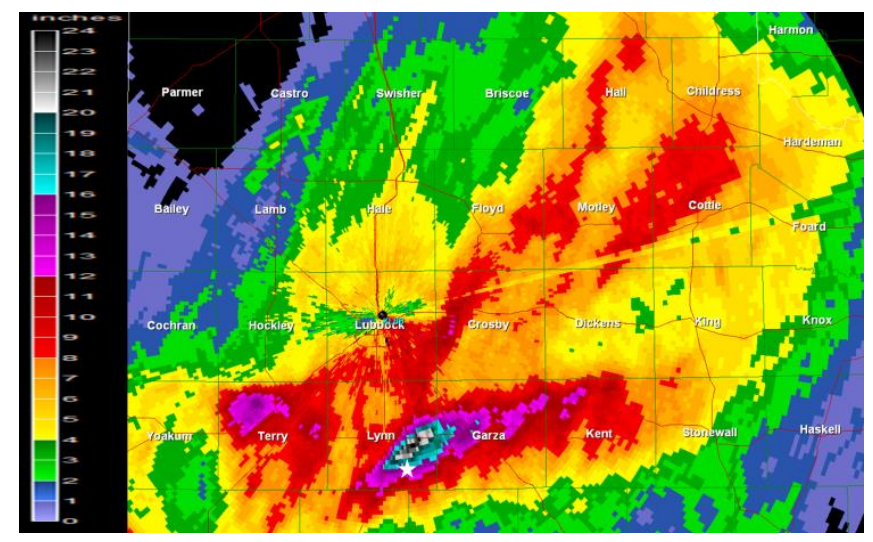

Figure 6. Storm total precipitation (in; multiply by 25.4 for $\mathrm{mm}$ ) estimation from KLBB for 0000 UTC 29 June-0000 UTC 5 July 2010. The white star indicates the location of maximum observed rainfall of $361 \mathrm{~mm}$ (14.2 in).

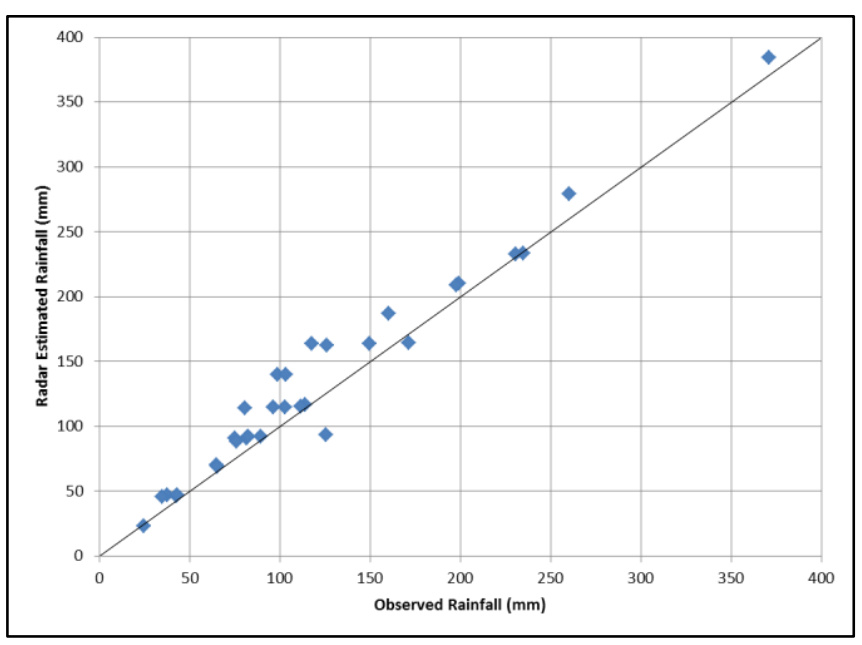

Figure 7. Scatter plot comparing observed rainfall amounts (mm) on the $x$ axis to radar estimated rainfall $(\mathrm{mm})$ on the $y$ axis. The solid black line indicates a perfect radar rainfall estimation. Points above the line indicate an overestimation while points below the line indicate an underestimation.

in an underestimation of rainfall. These two simultaneous conditions may have counteracted each other, resulting in a fairly accurate depiction of rainfall from the WSR-88D. The remainder of this analysis will focus on the most devastating part of the event that took place on the evening of 3 July through the early morning of 4 July.

\section{Analysis \\ a. Lift and moisture}

Upper-levels (Fig. 8a) and midlevels (Fig. 8b) were characterized by a ridge over the eastern contiguous United States, with a long-wave trough over the western contiguous United States. West Texas was between these two features, providing southerly to southwesterly flow aloft. Wind speeds at $250 \mathrm{hPa}$ and $500 \mathrm{hPa}$ over West Texas were light with values ranging from $5 \mathrm{~m} \mathrm{~s}^{-1}(10 \mathrm{kt})$ to $8 \mathrm{~m} \mathrm{~s}^{-1}$ (15 kt). During the days leading up to the peak of the event, $500-\mathrm{hPa}$ heights were slowly decreasing (not shown). Additionally, weak but persistent Q-vector convergence was observed from 500 to $300 \mathrm{hPa}$ at 0000 UTC on 4 July. The most notable feature aloft was a $700-\mathrm{hPa}$ mesoscale convective vortex (MCV) seen in both model (Fig. 9) and satellite data (Fig. 10). This MCV developed from deep convection in northeastern Mexico late on 2 July into early on 3 July - along the Sierra Madre Oriental Mountain range. Cloud top temperatures from convection in northeastern Mexico were $<-80^{\circ} \mathrm{C}$ at times. The MCV was first observed in visible satellite imagery in southeastern New Mexico, then it moved into West Texas just south of Lubbock on the evening of the third. This mesoscale feature was the primary mechanism of lift during the peak of the event.

Persistent moist isentropic ascent was observed throughout the entire episode. Isentropic lift was maximized in the 310-315-K layer for the entire duration of the event, but peaked on the evening of 3 July. Omega values of $-15 \mathrm{dPa} \mathrm{s}^{-1}$ were seen in the Rapid Update Cycle (RUC; Benjamin et al. 2002) 20-km grid on the $315-\mathrm{K}$ isentropic surface at 0900 UTC 4 July, with winds between $13 \mathrm{~m} \mathrm{~s}^{-1}(25 \mathrm{kt})$ and $15 \mathrm{~m} \mathrm{~s}^{-1}$ (30 kt; Fig. 11). This area of lift coincided with the area of maximum precipitation seen in Fig. 6 .

Southerly winds supported a continuous stream of moist air throughout the entire event (Fig. 12). Moisture transport vectors indicated that tropical cyclone Alex provided abundant amounts of moisture. Broad but continual moisture was being advected into the region by low-level jet (LLJ) winds at $850 \mathrm{hPa}$ between $10 \mathrm{~m} \mathrm{~s}^{-1}(20 \mathrm{kt})$ and $13 \mathrm{~m} \mathrm{~s}^{-1}$ (25 kt; Fig. 13). The strongest $850-\mathrm{hPa}$ winds were located near the position of the MCV on the evening of 3 July. Deep 

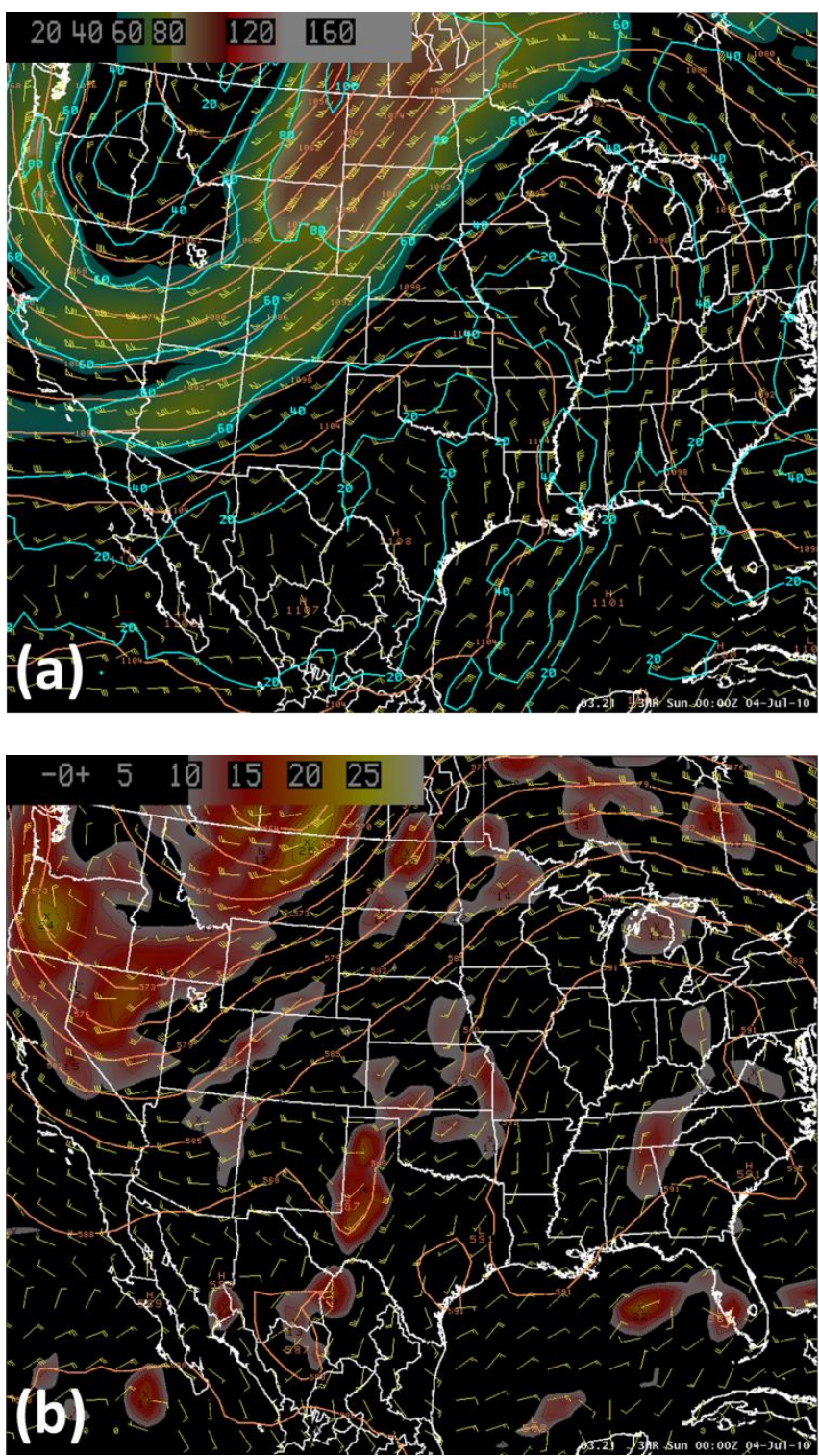

Figure 8. (a) RUC 3-h forecast at $250 \mathrm{hPa}$ valid 0000 UTC 4 July 2010. Thick tan lines are heights (every 6 dam); cyan lines are isotachs (every $10.3 \mathrm{~m} \mathrm{~s}^{-1}$ or $20 \mathrm{kt}$ ); and wind speeds $>28.3 \mathrm{~m} \mathrm{~s}^{-1}$ (>55 kt) are shaded. (b) RUC 3-h forecast at $500 \mathrm{hPa}$ valid 0000 UTC 4 July 2010. Dashed black lines indicate vorticity (every $1 \times$ $10^{-5} \mathrm{~s}^{-1}$ ) with values $>10 \times 10^{-5} \mathrm{~s}^{-1}$ shaded; thick tan lines are heights (every 2 dam).

moist convection was able to be maintained and intensified by the interaction of these two features (Schumacher and Johnson 2009). Mixing ratios within the LLJ were between 14 and $15 \mathrm{~g} \mathrm{~kg}^{-1}$ and encompassed much of West Texas on the morning of 4 July, including areas upstream of heavy rainfall. Relatively large equivalent potential temperatures also were observed coinciding with the large mixing ratios.

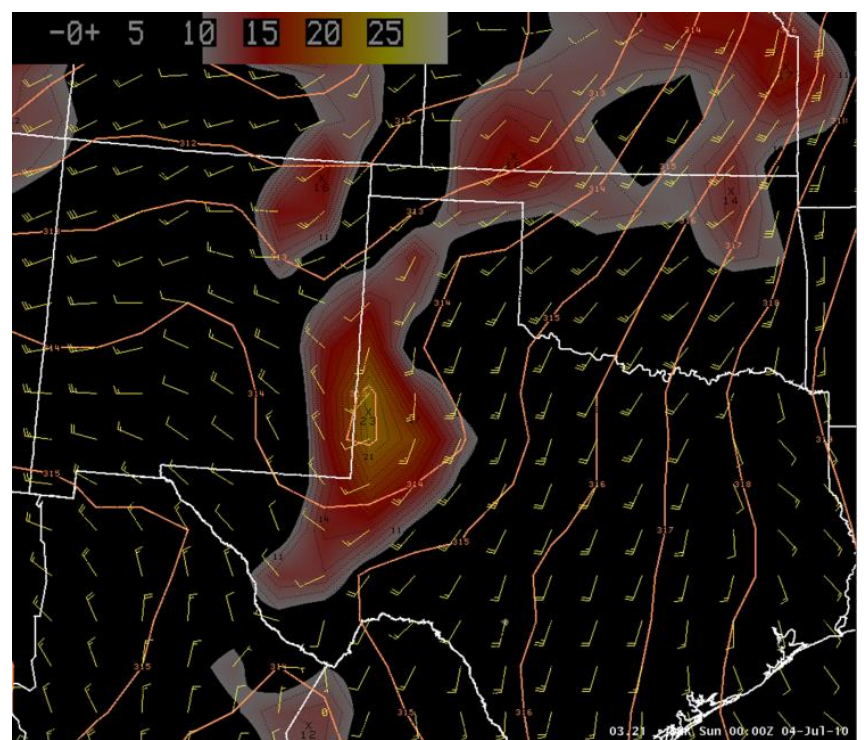

Figure 9. RUC 3-h forecast at $700 \mathrm{hPa}$ valid 0000 UTC 4 July 2010. Dashed black lines indicate vorticity (every $1 \times 10^{-5} \mathrm{~s}^{-1}$ ) with values $>10 \times 10^{-5} \mathrm{~s}^{-1}$ shaded; thick tan lines are heights (every 1 dam).

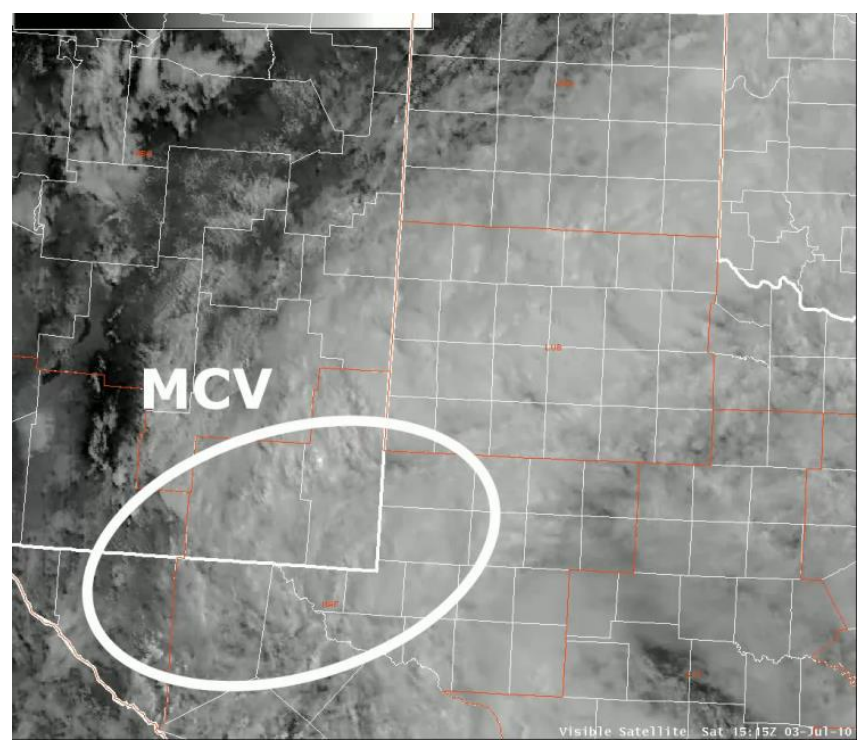

Figure 10. Animated visible satellite image of West Texas and eastern New Mexico from 1515 UTC 3 July through 2301 UTC 3 July 2010. Click image for an external animation.

\section{b. Warm-rain processes and instability}

Model soundings from the RUC depicted ingredients for heavy rainfall. A model sounding taken at 1800 UTC 3 July (Fig. 14) - prior to the peak of the event and near the location of heaviest rainfall just to the south of Lubbock - showed nearly saturated conditions at all levels. Note that this model sounding was taken prior to the beginning of rainfall on 3 July so it was determined to be a representative depiction of the 


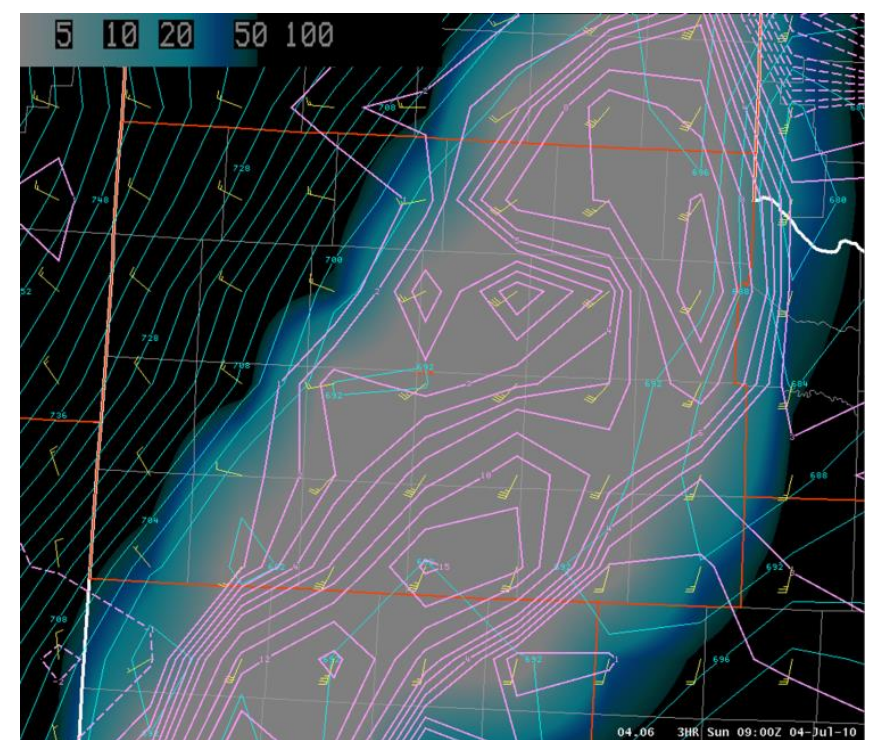

Figure 11. RUC 3-h forecast for the $315-\mathrm{K}$ isentropic surface valid 0900 UTC 4 July 2010. Condensation pressure deficit is shaded for values $<50 \mathrm{hPa}$. Solid blue lines are isobars (every $4 \mathrm{hPa}$ ). Omega $\left(\mathrm{dPa} \mathrm{s}^{-1}\right)$ is displayed in pink with upward motion indicated by solid lines and downward motion as dashed lines (every $1 \mathrm{dPa} \mathrm{s}^{-1}$ ).

surrounding atmosphere. The precipitable water was markedly large at $47 \mathrm{~mm}$ (1.84 in). This value was approximately $165 \%$ of normal. Although not shown, a sounding from Amarillo, Texas, at 1200 UTC 3 July depicted the largest precipitable water value ever recorded for July at $48 \mathrm{~mm}$ (1.87 in). Likewise, a sounding at Midland, Texas, observed the third largest July precipitable water value at $52 \mathrm{~mm}$ (2.03 in; NWS 2014). Warm cloud depth, which is defined here as the distance between the lifted condensation level (LCL) to the $0^{\circ} \mathrm{C}$ isotherm, approached $4.2 \mathrm{~km}(13.9 \mathrm{kft})$. The depth of the layer from the LCL to $-10^{\circ} \mathrm{C}$ was a remarkable $7.9 \mathrm{~km}(25.8 \mathrm{kft})$. At locations between the $0^{\circ} \mathrm{C}$ and $-10^{\circ} \mathrm{C}$ isotherms, most cloud particles are composed of supercooled water because ice nuclei are not activated until temperatures reach $<-10^{\circ} \mathrm{C}$ (NWS 2012). Taking this into consideration, the deeper the layer from the LCL to $-10^{\circ} \mathrm{C}$ the more enhanced the warm-rain precipitation production process.

An additional enhancement to precipitation production was light winds throughout the cloud-bearing layer. Winds from the LCL through the equilibrium level (EL) were nearly unidirectional, except for the lowest levels, where winds veered with height. However, speed shear was weak with values between $8 \mathrm{~m}$ $\mathrm{s}^{-1}(15 \mathrm{kt})$ and $13 \mathrm{~m} \mathrm{~s}^{-1}(25 \mathrm{kt})$. This led to minimal entrainment of dry air into the cloud and little evaporation before reaching the ground. The positive convective available potential energy (CAPE) from the 1800
UTC 3 July sounding (gray area on Fig. 14) was 388 $\mathrm{J} \mathrm{kg}^{-1}$. This value was determined from the mostunstable parcel, which was near the surface. The CAPE showed a narrow profile and was distributed over a large portion of the sounding. Additionally, the EL was at $335 \mathrm{hPa}$, which was much lower than the tropopause level of $169 \mathrm{hPa}$. All of these characteristics likely led to a limited amount of ice in the precipitation production process. Because of relatively weak updrafts and the lack of significant quantities of ice in the precipitation production process, little lightning was observed. The above characteristics resulted in a devastating heavy rain event that caused significant flooding and flash flooding.

\section{Hydrological issues}

Typically dry streams and creek beds experienced flooding during the July 2010 Independence Day holiday weekend rains in West Texas. The most dramatic and notable hydrological event occurred at the headwaters of the Double Mountain Fork of the Upper Brazos River. The 361-384 mm (14.21-15.12 in) of rainfall previously noted near Draw, Texas, extended over a large area of farmland. The area that received $>381 \mathrm{~mm}$ (15 in), on the order of 260 to $390 \mathrm{~km}^{2}$ (100 to $150 \mathrm{mi}^{2}$ ), does not normally contribute to the catchment area of the headwaters of the Upper Brazos River. On the southern plains of West Texas, runoff typically flows into the nearest playa lake or crop terrace and is captured at that location. However, during extreme events like the one described herein, small playa lakes fill to capacity and will overspread from one playa lake to the next. Eventually, the entire area of plains begins to see widespread overland flow (Fig. 15); this greatly increases the effective watershed of the river.

A portion of this overland flow ultimately led to the catastrophic failure of an earthen dam at Stuart Lake. Stuart Lake was a privately owned lake with a surface area of approximately $2.4 \times 10^{5} \mathrm{~m}^{2}(60 \mathrm{ac})$ in eastern Lynn County (Figs. 16 and 17). The lake's water and associated flood wave propagated down the Double Mountain Fork of the Upper Brazos and destroyed several oil pipelines. Flood waters-mixed with 165 barrels of crude oil-emptied into the Double Mountain Fork of the Upper Brazos River and Lake Alan Henry (NCDC 2010). Lake Alan Henry is a reservoir located $50 \mathrm{~km}(31 \mathrm{mi})$ east of Stuart Lake along the Double Mountain Fork and is operated by the city of Lubbock for water supply and recreation. 

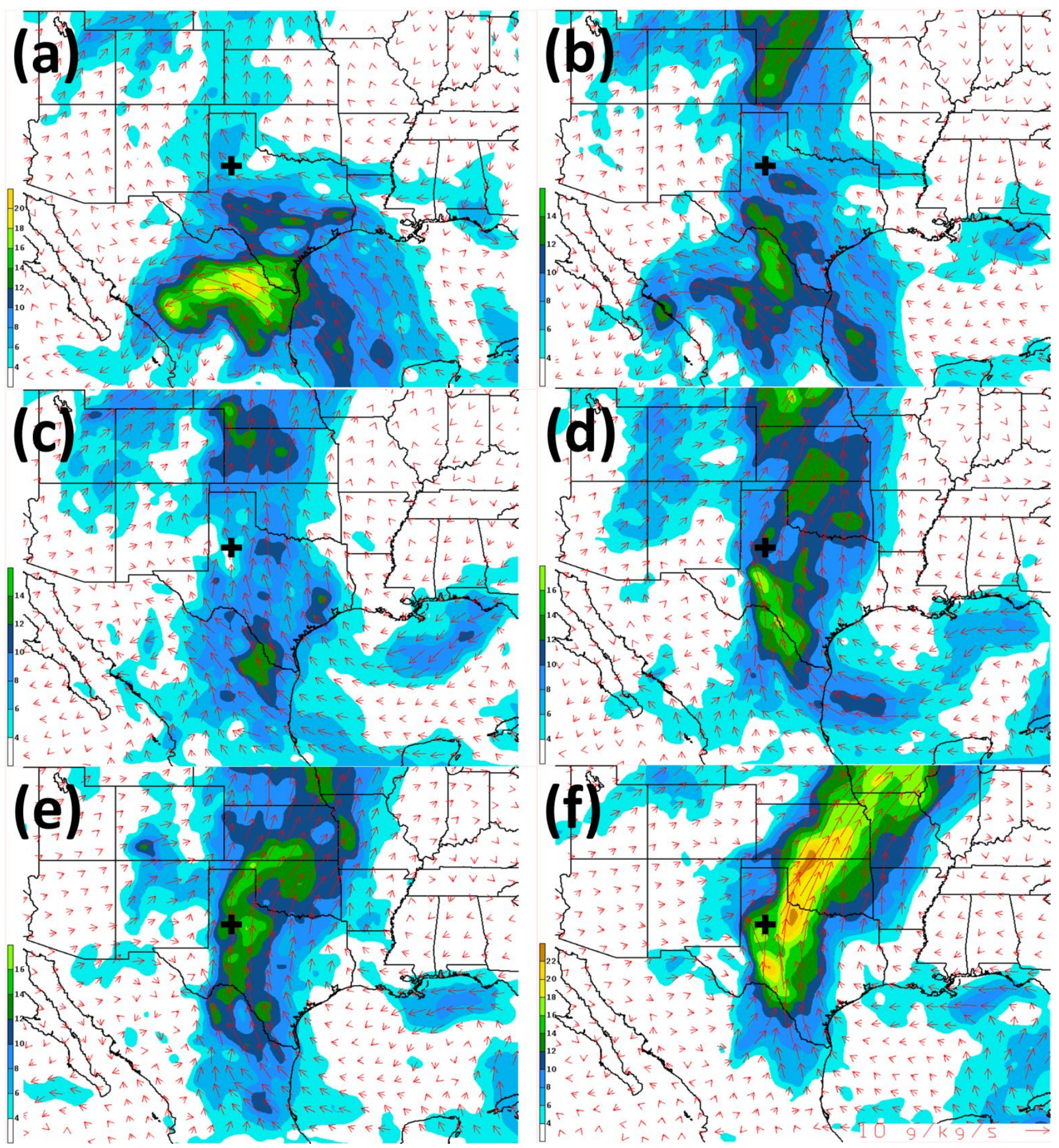

Figure 12. RUC depictions of the 850-500-hPa moisture transport vectors and magnitude $\left(\mathrm{g} \mathrm{kg}^{-1} \mathrm{~s}^{-1}\right)$ at (a) $0000 \mathrm{UTC} 2 \mathrm{July}$, (b) 1200 UTC 2 July, (c) 0000 UTC 3 July, (d) 1200 UTC 3 July, (e) 0000 UTC 4 July, and (f) 1200 UTC 4 July. Values $>4 \mathrm{~g} \mathrm{~kg}^{-1} \mathrm{~s}^{-1}$ are shaded. The location of heaviest rainfall is denoted by the bold + symbol.

Lake Alan Henry, which was full prior to the rainfall event with about $1.17 \times 10^{8} \mathrm{~m}^{3}$ (94 $\left.800 \mathrm{ac}-\mathrm{ft}\right)$ of water, saw an inflow from the Double Mountain Fork of around $6.66 \times 10^{7} \mathrm{~m}^{3}$ (54 000 ac-ft) during July 2010 .
Nearly $4.93 \times 10^{7} \mathrm{~m}^{3}(40000 \mathrm{ac}-\mathrm{ft})$ of that water flowed into the lake in the $24-48$-h period following this rain event. The annual discharge into Lake Alan Henry for 2010 was $1.02 \times 10^{8} \mathrm{~m}^{3}(82500 \mathrm{ac}-\mathrm{ft})$ with 


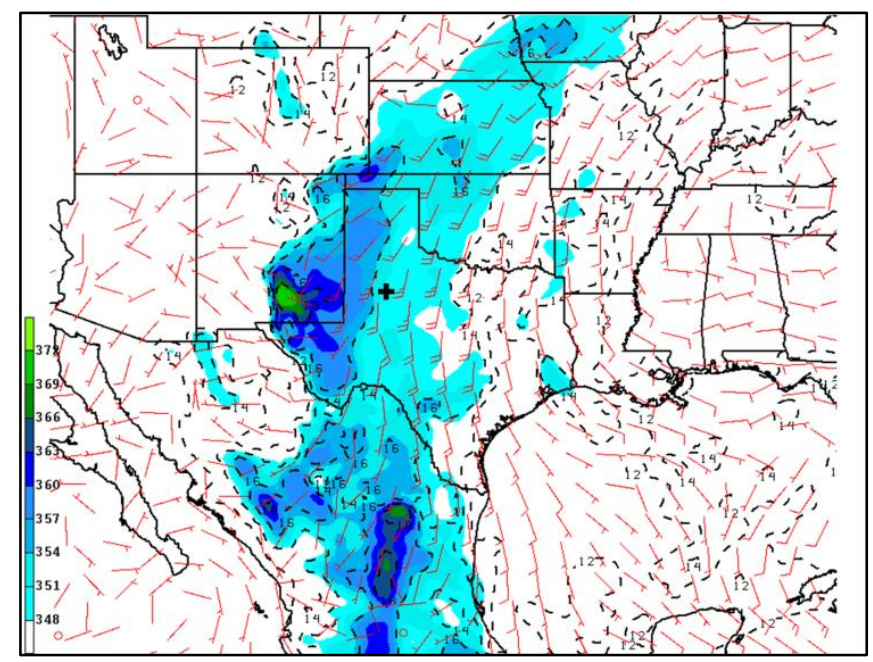

Figure 13. RUC initialization at $850-\mathrm{hPa}$ valid 1200 UTC 4 July 2010 displaying the wind barbs (kt, red), mixing ratio $>12 \mathrm{~g} \mathrm{~kg}^{-1}$ (dashed black every $2 \mathrm{~g} \mathrm{~kg}^{-1}$ ), and equivalent potential temperature $>348 \mathrm{~K}$ (shaded every $3 \mathrm{~K}$ ). The location of heaviest rainfall is denoted by the bold + symbol.

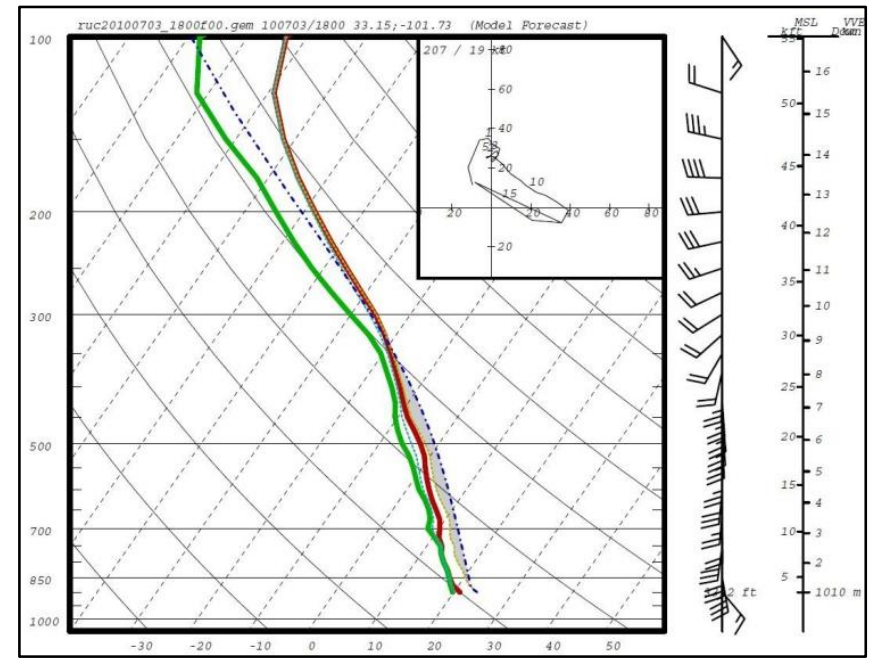

Figure 14. RUC initialization sounding valid 1800 UTC 03 July 2010 at the location of observed heaviest rainfall. The vertical scale on the left is in $\mathrm{hPa}$ and the horizontal scale is in ${ }^{\circ} \mathrm{C}$. The red line is temperature while the green line is dew point. The shaded portion represents positive CAPE.

July 2010 accounting for nearly two-thirds of this inflow. From records beginning in 1961 at the Justiceburg river gauge, $39 \mathrm{~km}$ (24 mi) east of Stuart Lake, the previous record flow for this section of the river was around $3.95 \times 10^{7} \mathrm{~m}^{3}(32000 \mathrm{ac}-\mathrm{ft})$ of water that occurred in June 1967, about 27 years before Lake Alan Henry was completed [United States Geological Survey (USGS) 2010]. Table 1 provides a summary of the flow statistics.
Table 1. Summary of flow statistics into Lake Alan Henry including the discharge into Lake Alan Henry for 2010, July 2010, and 24-48 h after 4 July 2010. The water storage of Lake Alan Henry prior to the event also is provided.

\begin{tabular}{|c|c|}
\hline & Volume of Water in $\mathbf{~ m}^{\mathbf{3}}$ (ac-ft) \\
\hline $\begin{array}{c}\text { Lake Alan Henry Water Storage } \\
\text { Prior to Event }\end{array}$ & $1.17 \times 10^{8}(94800)$ \\
\hline $\begin{array}{c}2010 \text { Annual Discharge into Lake } \\
\text { Alan Henry }\end{array}$ & $1.02 \times 10^{8}(82500)$ \\
\hline $\begin{array}{c}\text { July 2010 Discharge into Lake } \\
\text { Alan Henry }\end{array}$ & $6.66 \times 10^{7}(54000)$ \\
\hline $\begin{array}{c}\text { Discharge into Lake Alan Henry } \\
24-48 \text { h after 4 July 2010 }\end{array}$ & $4.93 \times 10^{7}(40000)$ \\
\hline
\end{tabular}

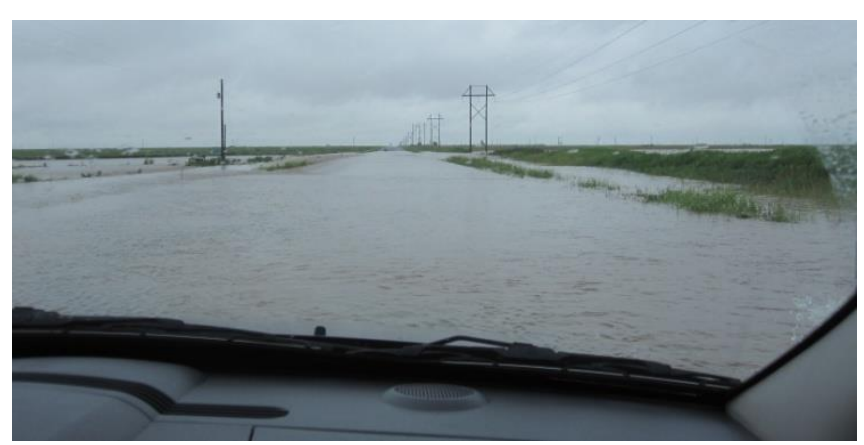

Figure 15. A survey following the event showing an area of overland flow nearly $1.6 \mathrm{~km}(1 \mathrm{mi})$ wide over US Route 380 between Post, TX, and Tahoka, TX.

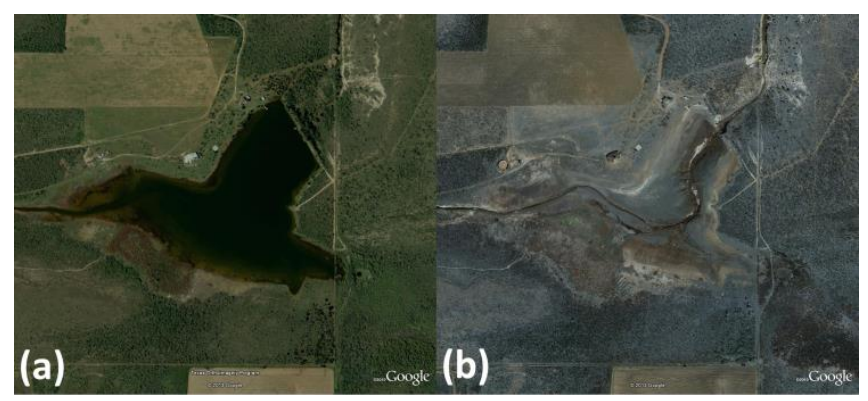

Figure 16. Google Earth imagery showing before and after images of Stuart Lake in Lynn County, TX, for (a) 1 April 2008 and (b) 24 February 2012.

\section{Wildfire impacts}

A long-term hydrometeorological influence of the 2010 Independence Day holiday weekend rainfall in West Texas was the enhancement of wildland vegetation and widespread fire during the subsequent cool season. As documented on the hemispheric scale by Veblen and Kitzberger (2002) - and locally on the southern Great Plains by Lindley et al. (2014) — positive growing season precipitation anomalies promote fire by inducing enhanced growth of herbaceous plants, which increases the availability of fine fuel. In 


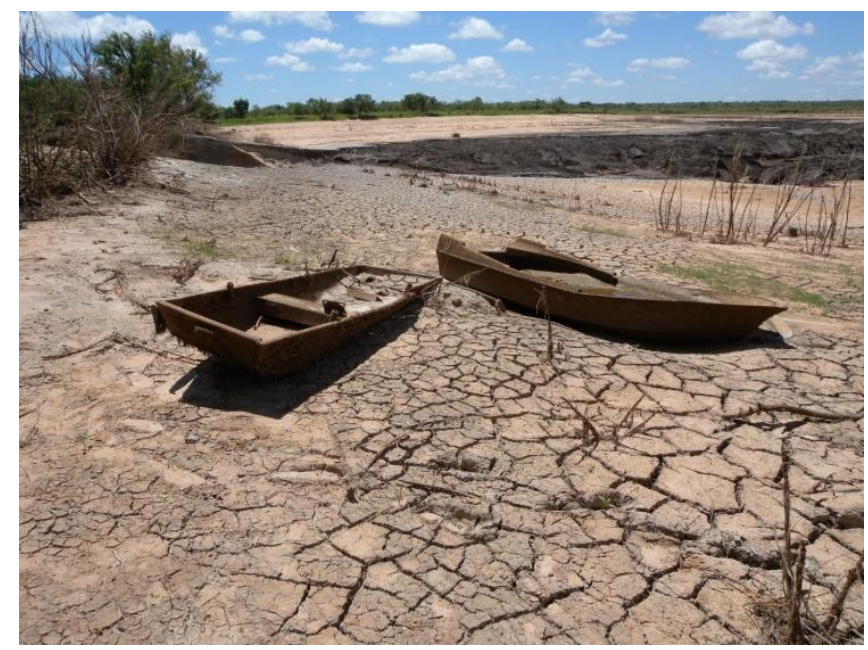

Figure 17. A survey following the catastrophic failure of an earthen dam at Stuart Lake depicting a bare Stuart Lake basin.

this regard, the early July rains associated with the remnants of Alex initiated a dramatic seasonal variability characterized by monthly precipitation totals from 200 to $400 \%$ above normal, which were followed by the onset of extreme drought. By January 2011, the same areas of southeastern New Mexico, West Texas, and western Oklahoma that had been impacted by Alex were subject to precipitation deficits totaling $<25 \%$ of normal (Fig. 18).

The effects of rain-enhanced vegetative build-up and subsequent drought-stricken curing of the West Texas fuelscape is reflected in plots of the energy release component (ERC; Bradshaw et al. 1983) from July 2010 through the spring and early summer of 2011 (Fig. 19). The ERC is a quantity directly related to the total energy per unit area of vegetative fuel, or the potential heat release available for burning in the flaming zone of a fire for a specific fuel model. Variables of ERC include weighted fuel loading (surface area-to-volume ratio) as well as a composite of live and dead large-fuel moistures (Cohen and Deeming 1985). The ERC is a cumulative index, and applies values from each of the previous seven days to successive calculations. As such, effects of day-to-day weather and fuel loading build over time as live fuels cure and dead fuels dry. Thus, the ERC is an excellent indicator of intermediate to long-term drying of vegetative fuels and, by extension, potential fire behavior.

Following a series of Arctic air masses that penetrated deep into the southern Great Plains between December 2010 and early February 2011, the onset of accelerated drying and curing of dormant season vegetation resulted in ERC values that exceeded the climatological 90th percentile and supported a series of destructive and widespread wildfire outbreaks. Averaged ERC values across West Texas ultimately eclipsed daily maximum values by mid-April and contributed to a historic wildfire season (Jones et al. 2013). The largest wildfires experienced in Texas during the unprecedented 2011 season occurred in the same areas of the state that were impacted by the Independence holiday weekend rains.

\section{Summary and conclusions}

Over a 4-day period from 1 July through 4 July 2010, historic rainfall and flooding occurred across the southern plains of West Texas. This event was historic in multiple aspects including the amount of rainfall, stream flows, and observed precipitable water values. Tropical moisture from a decaying Atlantic tropical system, Alex, provided abundant moisture along with subtle upper-level short waves supplying lift. The event reached its pinnacle on the evening of 3 July as an MCV progressed over West Texas. Rainfall rates exceeded $102 \mathrm{~mm} \mathrm{hr}^{-1}\left(4 \mathrm{in} \mathrm{hr}^{-1}\right)$ during the peak of the event with the maximum observed rainfall of 361 $\mathrm{mm}$ (14.2 in). The Lubbock WSR-88D utilized a tropical $Z-R$ relation prior to the beginning of rainfall in anticipation of obtaining better rainfall estimates. Because of this change, radar rainfall estimates were fairly accurate and only slightly overestimated based on observed values. A large swath of $406-610 \mathrm{~mm}$ (16-24 in) was depicted by radar rainfall estimates. A major reason for the excessive rainfall was the tropical characteristics of the atmosphere.

Warm-rain processes were greatly amplified during this event for several reasons. Model soundings depicted a nearly saturated atmosphere and precipitable water values well above normal. Light winds within the cloud-bearing layer led to scarce entrainment of dry air and little evaporation of rain before reaching the ground. Instability was weakly positive but "tall and narrow," which led to relatively weak updrafts and prevented deep moist convection that usually is identified in thunderstorms. Furthermore, weak updrafts led to sparse ice production within the cloud and thus minimal amounts of lightning. These characteristics, along with a deep warm cloud depth, led to tremendously efficient rainfall and subsequent flooding.

Flash flooding and river flooding are especially rare events on the southern High Plains of West Texas. When substantial heavy rain and flooding do occur, the effects are significant and can be devastating to 


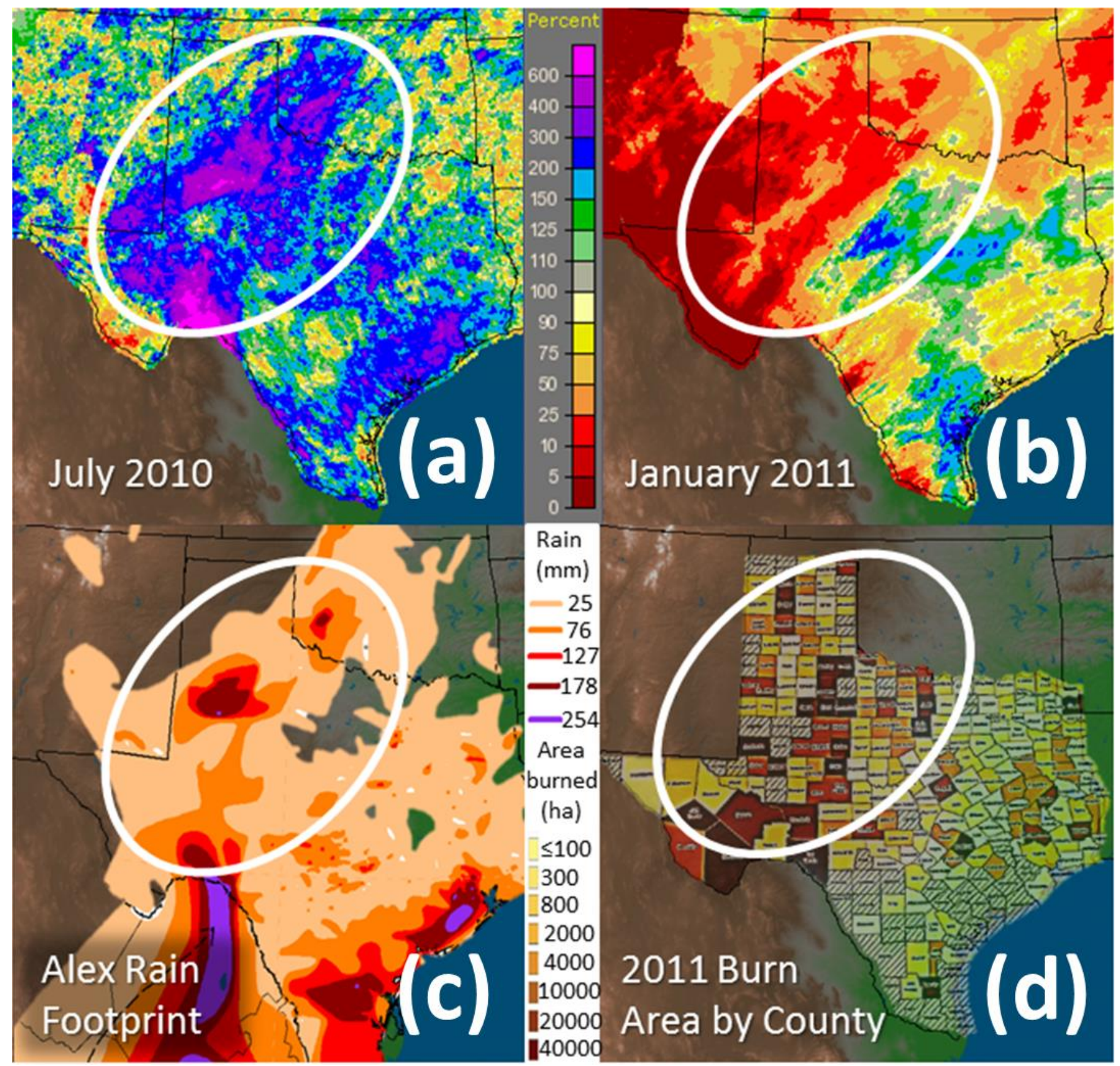

Figure 18. Percent of normal precipitation for (a) July 2010 and (b) January 2011. Shown for comparison is the (c) precipitation footprint of the tropical system, Alex, and (d) 2011 acres burned per county $\left(1 \mathrm{ac}=4046.86 \mathrm{~m}^{2}\right)$.

both urban and agricultural areas, as it was in this event. Unusual and continuous overland flow from one playa lake to the next contributed to the failure of an earthen dam and a release of significant headwaters into the Upper Brazos River. Total agricultural losses were estimated near $\$ 7$ million, with property losses estimated near $\$ 9.5$ million over a 3-day period. Although the impacts of this event were destructive to crops and property-including a hazardous material spill—no loss of life or significant injuries were reported.

A long-term effect from the heavy rains and flooding from this event ultimately was the enhancement of destructive wildfires across West Texas. Vegetative growth was improved by this rainfall, which was followed by a multi-year drought that led to an abundance of cured fuels. With the documentation of significant heavy rain events from tropical systems 


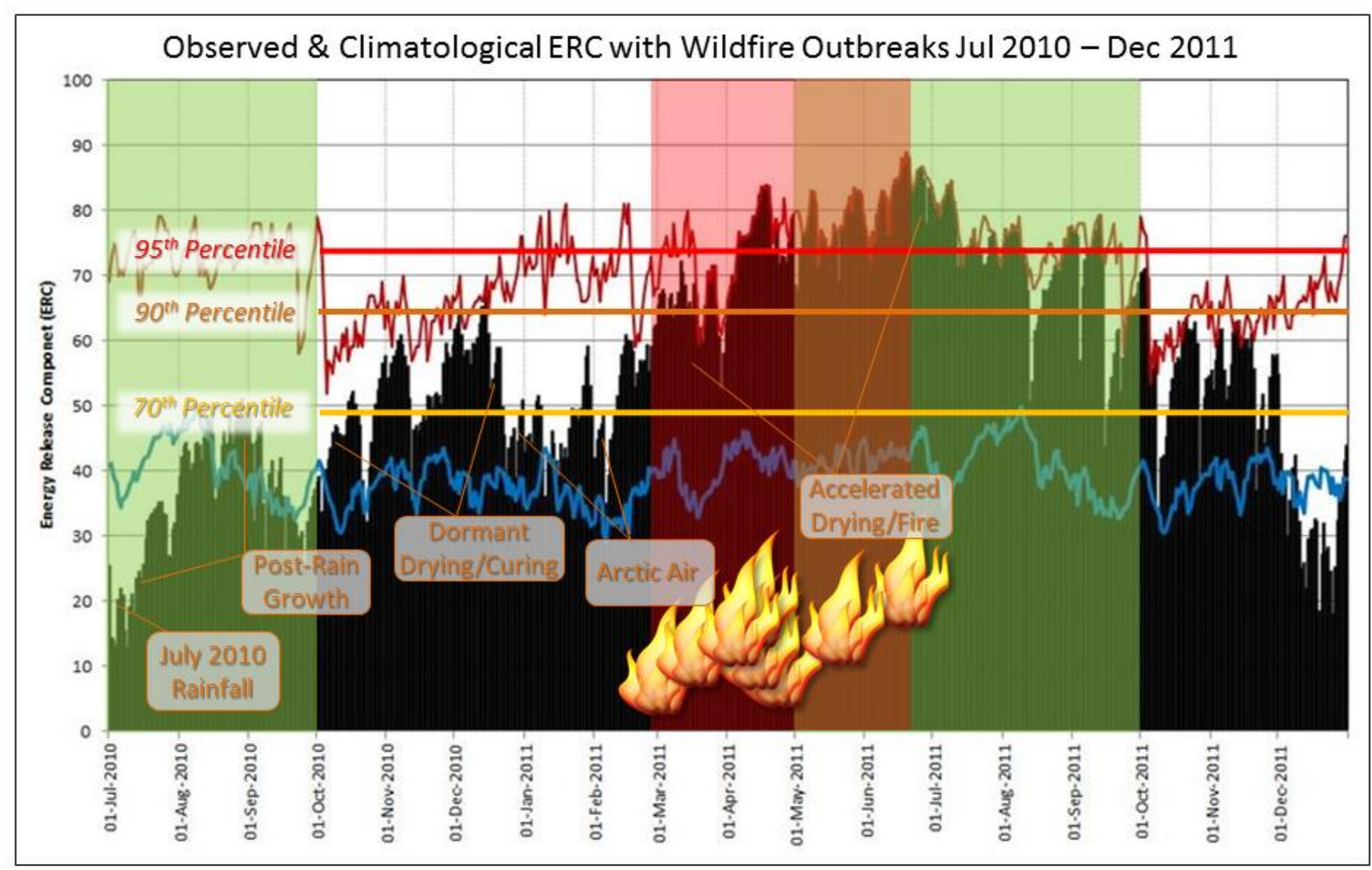

Figure 19. Daily averaged ERC in west Texas for July 2010-December 2011 with climatological daily mean (blue) and maximum (red) values, and 20-yr 70th percentile, 90th percentile, and 95th percentile rankings. The typical growing season (green shade) and range of 2011 southern Great Plains wildfire outbreaks (SGPWOs, red shade) is shown. Individual SGPWO occurrences are indicated (fire icons).

over West Texas, such as the one described in this study, operational forecasters can become increasingly aware of their impacts and be able to anticipate these types of anomalous events.

Although rare, the meteorological ingredients came together in concert for an unusually heavy rainfall event in West Texas. Without the introduction of an MCV, this may have been only a minor heavy rain event without the destructive effects observed in this case. Despite the fact that moisture and instability were well forecast, it was the MCV interaction with these features that led to excessive rainfall. It did not become apparent until the afternoon of 3 July that an MCV had formed. If operational forecasters are able to focus their efforts on areas of potentially enhanced lift, events such as this one can be anticipated more readily. Not only were the short-term effects in terms of flooding recognized, but long-term effects involving fire weather also can be better anticipated.

It is possible that events such as this one have occurred more frequently than currently known but have not been studied at great depth. A few impactful cases have been documented when tropical cyclones have affected West Texas, but a more precise frequency and severity could be determined based on past events. A more robust database could be built using the objectively determined Saint Louis University Cooperative Institute for Precipitation Systems analog guidance (Gravelle et al. 2009). This would be possible for future work, not just for the Lubbock NWS but for all of West Texas and neighboring regions.

Acknowledgments. The authors thank (i) Steve Cobb, Mark Conder, and Ron McQueen of the NWS in Lubbock, TX, for technical edits and suggestions, (ii) Doug Tilly of the NWS in St. Louis, MO, and (iii) Jon Zeitler of the NWS in New Braunfels, TX, for additional data.

\section{REFERENCES}

Benjamin, S. G., and Coauthors, 2002: The 20-km version of the RUC. Preprints, 14th Conf. on Numerical 
Weather Prediction, Fort Lauderdale, FL, Amer. Meteor. Soc., J2.3. [Available online at ams.confex.com/ams/pdfpapers/23336.pdf.]

Bomar, G. W., 1995: Texas Weather. 2nd ed. University of Texas Press, 275 pp.

Bosart, L. F., J. M. Cordeira, T. J. Galarneau Jr., B. J. Moore, and H. M. Archambault, 2012: An analysis of multiple predecessor rain events ahead of tropical cyclones Ike and Lowell: 10-15 September 2008. Mon. Wea. Rev., 140, 1081-1107, CrossRef.

Bradshaw, L. S., J. E. Deeming, R. E. Burgan, and J. D. Cohen, 1983: The 1978 National Fire-Danger Rating System: Technical documentation. USDA Forest Service General Tech. Rep. INT-169, 49 pp. [Available online at www.fs.fed.us/rm/pubs_int/int_gtr169.pdf?.]

Briere, P. R., 2000: Playa, playa lake, sabkha: Proposed definitions for old terms. J. Arid Environ., 45, 1-7, CrossRef.

Carey, L. D., and S. A. Rutledge, 2000: The relationship between precipitation and lightning in tropical island convection: A C-band polarimetric radar study. Mon. Wea. Rev., 128, 2687-2710, CrossRef.

Cohen, J. D., and J. E. Deeming, 1985: The National FireDanger Rating System: Basic equations. USDA Forest Service General Tech. Rep. PSW-82, 23 pp. [Available online at www.fs.fed.us/psw/publications/documents/ psw_gtr082/psw_gtr082.pdf.]

Gravelle, C. M., C. E. Graves, J. P. Gagan, F. H. Glass, and M. S. Evans, 2009: Winter weather guidance from regional historical analogs. Preprints, 23rd Conf. on Weather Analysis and Forecasting, Omaha, NE, Amer. Meteor. Soc., JP3.10. [Available online at ams.confex.com/ams/pdfpapers/154201.pdf.]

Jones, J., A. Saginor, and B. Smith, 2013: 2011 Texas wildfires: Common denominators of home destruction. Texas A\&M Forest Service, $52 \mathrm{pp}$. [Available online at texasforestservice.tamu.edu/uploadedFiles/FRP/New__Mitigation/Safety_Tips/2011\%20Texas\%20Wildfires. pdf.]

Lindley, T., A. Lyster, and R. Gould, 2005: Observations of a tropical storm in West Texas. Electronic $J$. Operational Meteor., 6 (2), 1-9. [Available online at www.nwas.org/ej/pdf/2005-EJ2.pdf.]

, J. D. Vitale, W. S. Burgett, and M.-J. Beierle, 2011: Proximity meteorological observations for wind-driven grassland wildfire starts on the southern High Plains. Electronic J. Severe Storms Meteor., 6 (1), 1-27. [Available online at ejssm.org/ojs/index.php/ejssm/ article/view/67/61.] and Coauthors, 2014: Southern Great Plains wildfire outbreaks. Electronic J. Severe Storms Meteor., 9 (2), 1-43. [Available online at ejssm.org/ojs/index.php lejssm/article/view/132/98.]

NCDC, 2010: Storm Data, 52 (7), 798 pp. [Available online at www.ncdc.noaa.gov/IPS/sd/sd.html.]

NHC, cited 2012: NHC data archive. [Available online at www.nhc.noaa.gov/data/.]

NWS, cited 2012: Introduction to the top-down methodology. [Available online at www.wdtb.noaa.gov /courses/winterawoc/IC6/lesson1/player.html.] cited 2014: Upper-air climatology. [Available online at www.weather.gov/unr/uac.]

Pasch, R. J., 2010: Tropical cyclone report Hurricane Alex (AL012010) 25 June-2 July 2010. NHC Report, 19 pp. [Available online at www.nhc.noaa.gov/pdf/TCRAL012010_Alex.pdf.]

Rosenfield, D., D. B. Wolff, and D. Atlas, 1993: General probability-matched relations between radar reflectivity and rain rate. J. Appl. Meteor., 32, 50-72, CrossRef.

Schumacher, R. S., and R. H. Johnson, 2009: Quasistationary, extreme-rain-producing convective systems associated with midlevel cyclonic circulations. Wea. Forecasting, 24, 555-574, CrossRef.

Simpson, R. H., and J. M. Pelissier, 1971: Atlantic hurricane season of 1970. Mon. Wea. Rev., 99, 269-277, CrossRef.

Tumbiolo, J. L., 1989: Analysis of Northeast Pacific Hurricane Tico and its associated heavy rain event over the South Plains of Texas and Oklahoma. M.S. thesis, Dept. of Geosciences, Texas Tech University, 182 pp. [Available online at repositories.tdl.org/ttu-ir/bitstream /handle/2346/11854/31295005508055.pdf.]

USGS, cited 2010: USGS water data for Texas. [Available online at nwis.waterdata.usgs.gov/tx/nwis/.]

Veblen, T. T., and T. Kitzberger, 2002: Inter-hemispheric comparison of fire history: The Colorado Front Range, U.S.A., and the northern Patagonian Andes, Argentina. Plant Ecol., 163, 187-207, CrossRef.

Vitale, J. D., and T. Ryan, 2013: Operational recognition of high precipitation efficiency and low-echo-centroid convection. J. Operational Meteor., 1 (12), 128-143, CrossRef.

Xu, X., K. Howard, and J. Zhang, 2008: An automated radar technique for the identification of tropical precipitation. J. Hydrometeor., 9, 885-902, CrossRef. 